\title{
Treatment of polyarteritis nodosa related to hepatitis $B$ virus with interferon-alpha and plasma exchanges
}

Loïc Guillevin, François Lhote, Françoise Sauvaget, Pierre Deblois, François Rossi, Daniel Levallois, Jacques Pourrat, Boyan Christoforov, Christian Trépo
Department of

Internal Medicine,

Hôpital Avicenne,

125 route de

Stalingrad,

93009 Bobigny,

France

L Guillevin

F Lhote

F Sauvaget

Department of

Internal Medicine,

Hôpital Lariboisière,

Paris, France

P Deblois

Department of

Internal Medicine,

Centre Hospitalier de

Vendôme,

France

F Rossi

Department of

Internal Medicine,

Centre Hospitalier de

Blois,

France

D Levallois

Department of

Nephrology,

Hôpital Purpan,

Toulouse, France

J Pourrat

Department of

Internal Medicine,

Hôpital Cochin,

Paris, France

B Christoforov

Hepatogastroenterology

Unit and INSERM

Hepatitis Research

Unit (U271),

Hôtel-Dieu,

Lyon, France

C Trépo

Correspondence to:

Dr L Guillevin

Service de Médecine Interne,

Hôpital Avicenne

125 , route de Stalingrad,

93009 Bobigny Cedex,

France.

Accepted for publication

11 February 1994

\begin{abstract}
Objectives-To test the effectiveness of and tolerance to interferon-alpha $2 b$ (INFa2b) in association with plasma exchanges for the treatment of polyarteritis nodosa (PAN) related to hepatitis $B$ virus (HBV).
\end{abstract}

Methods-A prospective, non blinded, multicentre trial was carried out in which patients with multisystemic $\mathrm{HBV}$-related PAN were included. Each patient received the association of INFa2b and plasma exchanges. The end point of the study was control of the disease (recovery or remission) or death.

Results-Six patients were included in the study. Each patient had histopathological or arteriographic evidence of vasculitis and was infected with actively replicating HBV. All patients were alive at the end of the study and no longer presented clinical or laboratory evidence of systemic vasculitis. HBeAg/anti-HBeAb seroconversion was observed in four patients $(66.6 \%)$ and HBsAg/anti-HBsAb in $3 / 6$ $(50 \%)$. Two patients are still being treated with INFa2b because of chronic active hepatitis.

Conclusions-It is considered that this new therapeutic approach to HBV-related PAN effectively cured systemic vasculitis and was associated with control of $\mathrm{HBV}$ infections. Antiviral therapy may have a role to play as the first line treatment regime of virus-induced vasculitis.

(Ann Rheum Dis 1994; 53: 334-337)

Polyarteritis nodosa (PAN) is a well-known form of necrotising angiitis. The association of PAN with hepatitis $B$ virus (HBV) was described in $1970^{3}$ and has been confirmed by many previous reports. ${ }^{2}$ In our experience, ${ }^{4-6}$ the evolution of PAN and HBV infection were usually dissociated in patients with HBVrelated PAN treated with steroids and immunosuppressive drugs such as cyclophosphamide. Most of the patients who recovered from PAN had chronic $\mathrm{HBV}$ infections and in some cases we observed a progression to cirrhosis. In a previous study, ${ }^{7}$ we reported the effectiveness of the association of a short term steroid treatment followed by the combination of vidarabine (Vira A), plasma exchanges in the treatment of HBV-related PAN. The purpose of this study was to test a new antiviral agent, $\mathrm{INFa} 2 \mathrm{~b}$, in association with plasma exchanges as the first-line treatment of HBV-related PAN.

\section{Patients and methods}

PATIENTS

Criteria for entry into the study were similar to those previously described. ${ }^{7}$ All patients had PAN with multiple system involvement; histological or angiographic evidence of vascular lesions indicative of a diagnosis of vasculitis; HBV infection with active viral replication. Previous treatment with steroids, cyclophosphamide and Vira A were considered exclusion criteria. Patients were consecutively enrolled in the trial. Recruitment began in January 1988. The end point of the study was control of the disease (recovery and remission, as defined below) or the patient's death. The study protocol was approved by the Biomedical Ethics Committee of the University of Paris-Nord.

TREATMENT PROTOCOL

Prednisone. Administration of prednisone was optional and given only in the case of severe or life-threatening manifestations of PAN. When given, every patient took prednisone at a dose of $1 \mathrm{mg} / \mathrm{kg} /$ day during the first week of treatment. The prednisone dose was rapidly tapered and steroids were stopped at the end of the second week. In the case of failure of the assigned treatment (lack of clinical improvement or relapse), prednisone was given again at a dose of $1 \mathrm{mg} / \mathrm{kg} /$ day.

Interferon-alpha $2 b$ (INFa2b). INFa2b was started just after the patient's inclusion in the study. It was initiated at a dose of 3 million units, three times a week. The treatment duration depended on the results of $\mathrm{HBV}$ replication tests. In the case of seroconversion within the weeks following $\mathrm{INFa} 2 \mathrm{~b}$, the antiviral treatment was stopped. If $\mathrm{HBe}$ antigenaemia remained positive, $\mathrm{INFa} 2 \mathrm{~b}$ was administered for one year and additional treatments could be given later on, depending on the patient's liver function status.

PLASMA EXCHANGES ${ }^{8}$

Every patient had plasma exchanges, which were started just after the patient's inclusion in 
the study. Each patient had nine to 12 plasma exchanges during the first three weeks of treatment with INFa2b. During this period, the number of plasma exchanges depended on vascular access and the level of clotting factors before plasma exchanges. After this period, plasma exchanges were performed two or three times a week, depending on the clinical results observed, and then stopped. The amount of plasma scheduled to be exchanged during each session was $60 \mathrm{ml} / \mathrm{kg}$ of body weight. The replacement fluid consisted of $500 \mathrm{ml}$ of fluid gelatin and $4 \%$ albumin.

SEROLOGICAL ASSAYS

Patients' sera were tested with commercial radioimmunoassays (Abbott) for the presence of $\mathrm{HBsAg}$, anti-HBsAb and anti-HBcAb and, when $\mathrm{HBsAg}$ positive, for $\mathrm{HBeAg}$ and anti$\mathrm{HBeAb}$. The presence of HBV DNA in the sera was assayed using a spot hybridisation technique and HBV DNA polymerase as previously described. ${ }^{9}$

\section{EVALUATION OF DISEASE ACTIVITY}

The disease was controlled when the patient's general condition improved; no new clinical manifestations related to PAN developed; the erythrocyte sedimentation rate (ESR) became normalised. Stabilisation or improvement (partial or total) of peripheral neuropathy and renal and cardiac function (if abnormalities existed previously) was also necessary. The patient was considered to be completely recovered from PAN when the required criteria for control of the disease were met and maintained for at least 12 months after discontinuation of treatment, or when $\mathrm{HBeAg} / \mathrm{anti}-\mathrm{HBeAb}$ seroconversion had also been obtained six months after discontinuation of treatment. Clinical remission was achieved when clinical symptoms became attenuated or improved and laboratory abnormalities returned to normal under constant treatment. If there was no evidence of control of the disease activity under the assigned treatment or if a relapse (new systemic manifestations of PAN or worsening of the initial manifestations of the disease) occurred, the trial was stopped, and the patient was withdrawn from the study. Withdrawal from the study because of assigned treatment failure was recorded by the coordinating committee.

FOLLOW UP EVALUATIONS

The clinical and laboratory data were collected at the time of inclusion in the study, 15 and 30 days later (45 days after study entry), then every month for six months, every three months for one year, and every six months for the next five years. In case of a relapse or incomplete control of the disease, additional tests were performed.

\section{Results}

Between January 1988 and June 1992, six patients were eligible for the study.

\section{CLINICAL FINDINGS}

The clinical manifestations of PAN in the six study patients are summarised in the table. Of the six patients, four were men and two were women; their mean (SD) age at inclusion was $56 \cdot 5(14 \cdot 1)$ years (range: $36-72$ years). In four of six patients it was possible to determine the origin of the contamination with HBV: blood transfusion in patient 6; homosexual contact with serum HBsAg-positive partners (in cases 1 and 3); dental treatments were the only suspected risk factor in patient 4. Three patients presented clinical signs of acute viral hepatitis before developing PAN within 15 days, one and 37 months (respectively cases 1 , 4 and 6).

Histopathological or angiographic evidence of vasculitis was found in all six patients. All our six patients met the diagnostic criteria defined by the American College of Rheumatology. ${ }^{3}$

\section{LABORATORY FINDINGS}

Renal failure, present in one case (serum creatinine: $2.4 \mathrm{mg} / \mathrm{dl}$ ) was the result of membranous glomerulonephritis associated with renal vasculitis. Antineutrophil cytoplasmic antibodies were not found in any patient. HBsAg and HBeAg were always present and IgM anti-HBc was positive in patient 1 . Viral DNA and/or DNA polymerase was obtained in five of six patients and the replication level was high in every case. Transaminases were elevated in three patients.

During the weeks after the onset of treatment, transaminases decreased when they had previously been high and, conversely, no increase in transaminases was noted. After treatment, $4 / 6$ patients $(66.6 \%)$ seroconverted to anti-HBeAb and three $(50 \%)$ to anti$\mathrm{HBsAb}$. When obtained, $\mathrm{HBeAg} /$ anti-HBeAb and $\mathrm{HBsAg}$ /anti-HBsAb seroconversions occurred one, five, eight and 11 months after the beginning of treatment.

\section{LIVER BIOPSIES}

At the time of diagnosis, a liver biopsy was performed in $5 / 6$ patients. Histological evidence of persistent chronic hepatitis was present in one and chronic active hepatitis in four. The biopsy did not demonstrate hepatitis in one case but revealed necrotising vasculitis.

RESULTS OF PLASMA EXCHANGES

Ninety one plasma exchanges were performed. The mean number of plasma exchanges per patient was 15 (range: 5-35). The mean (SD) volume exchanged was $3825(400) \mathrm{ml}$. The side effects and complications of plasma exchanges were mild and transient.

\section{OUTCOME}

The mean (SD) follow up period was $19 \cdot 1$ $(20 \cdot 1)$ months (range: $10 \cdot 5-59 \cdot 8$ months). Disease activity was controlled in every patient during the first weeks of treatment. All six 
Clinical manifestations, laboratory data, histopathological and angiographic evidence of vasculitis, follow up in six patients with $H B V$ related PAN

\begin{tabular}{|c|c|c|c|c|c|c|c|c|c|}
\hline Number & Sex & Age & Symptoms & $\begin{array}{l}\text { Abnormal } \\
\text { laboratory data } \\
\text { at inclusion }\end{array}$ & Pathology ${ }^{\star}$ & $\begin{array}{l}\text { Liver } \\
\text { histology }\end{array}$ & Angiogram & 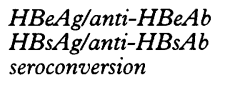 & $\begin{array}{l}\text { Outcome } \\
\text { HBV/PAN }\end{array}$ \\
\hline 1 & $\mathbf{F}$ & 36 & $\begin{array}{l}\text { weight loss, hypertension, } \\
\text { retinal vasculitis, CNS } \\
\text { involvement }\end{array}$ & $\begin{array}{l}\text { ASAT: } 120 \mathrm{IU} / \mathrm{I} \\
\text { ALAT: } 110 \mathrm{IU} / \mathrm{I}\end{array}$ & $\begin{array}{l}\text { neuromuscular } \\
\text { biopsy }\end{array}$ & $\begin{array}{c}\text { aggressive } \\
\text { hepatitis }\end{array}$ & normal & $\begin{array}{l}\text { no } \\
\text { no }\end{array}$ & $\begin{array}{l}\text { remission/ } \\
\text { recovered }\end{array}$ \\
\hline 2 & $\mathrm{~F}$ & 72 & cholecystitis, mononeuritis & $\begin{array}{l}\text { ASAT: } 80 \mathrm{IU} / \mathrm{I} \\
\text { ALAT: } 70 \mathrm{IU} / \mathrm{I}\end{array}$ & $\begin{array}{l}\text { liver and gall } \\
\text { bladder biopsies }\end{array}$ & $\begin{array}{l}\text { no hepatitis } \\
\text { vasculitis }\end{array}$ & ND & $\begin{array}{l}\text { yes }(5 \mathrm{mo}) \\
\text { yes }(5 \mathrm{mo})\end{array}$ & $\begin{array}{l}\text { recovered/ } \\
\text { recovered }\end{array}$ \\
\hline 3 & $M$ & 47 & $\begin{array}{l}\text { fever, weight loss, myalgias } \\
\text { malignant hypertension, } \\
\text { mononeuritis multiplex }\end{array}$ & & rectal biopsy & $\begin{array}{l}\text { aggressive } \\
\text { hepatitis }\end{array}$ & MAM, RI & $\begin{array}{l}\text { no } \\
\text { no }\end{array}$ & $\begin{array}{l}\text { remission/ } \\
\text { recovered }\end{array}$ \\
\hline 4 & M & 51 & $\begin{array}{l}\text { weight loss, myalgias, } \\
\text { polyarthritis, mononeuritis } \\
\text { multiplex }\end{array}$ & $\begin{array}{l}\text { ASAT: } 120 \mathrm{IU} / \mathrm{I} \\
\text { ALAT: } 280 \mathrm{IU} / \mathrm{I}\end{array}$ & $\begin{array}{l}\text { neuromuscular } \\
\text { biopsy }\end{array}$ & $\begin{array}{c}\text { aggressive } \\
\text { hepatitis }\end{array}$ & ND & $\begin{array}{l}\text { yes }(8 \mathrm{mo}) \\
\text { yes }(8 \mathrm{mo})\end{array}$ & $\begin{array}{l}\text { recovered/ } \\
\text { recovered }\end{array}$ \\
\hline 5 & M & 63 & $\begin{array}{l}\text { weight loss, fever, } \\
\text { Raynaud's phenomenon } \\
\text { mononeuritis multiplex }\end{array}$ & & $\begin{array}{l}\text { neuromuscular } \\
\text { biopsy }\end{array}$ & $\begin{array}{l}\text { persistent chronic } \\
\text { hepatitis, } \\
\text { vasculitis }\end{array}$ & normal & $\begin{array}{l}\text { yes (1 month) } \\
\text { no }\end{array}$ & $\begin{array}{l}\text { recovered/ } \\
\text { recovered }\end{array}$ \\
\hline 6 & $M$ & 70 & $\begin{array}{l}\text { myalgias, nephrotic } \\
\text { syndrome }\end{array}$ & creatinine: $2.4 \mathrm{mg} / \mathrm{dl}$ & renal biopsy & $\begin{array}{c}\text { aggressive } \\
\text { hepatitis }\end{array}$ & normal & $\begin{array}{l}\text { yes }(11 \mathrm{mo}) \\
\text { yes }(12 \mathrm{mo})\end{array}$ & $\begin{array}{l}\text { recovered/ } \\
\text { recovered }\end{array}$ \\
\hline
\end{tabular}

MAM: mesenteric artery microaneurysms, RI: renal infarcts. ND: not done ${ }^{\star}$ tissues with biopsy proven vasculitis.

ASAT: aspartate aminotransferase, ALAT: alanine aminotransferase, CS: corticosteroids.

patients were alive at the end of the study and had recovered completely from PAN; four of them had recovered from $\mathrm{HBV}$ as well and the remaining two are still being treated with $\mathrm{INFa} 2 \mathrm{~b}$ because of chronic active hepatitis but do not present any symptoms of PAN.

Sequelae of polyarteritis nodosa were present in three patients. One is handicapped by peripheral neuropathy, one (case 6 ) by renal failure (serum creatinine: $2.4 \mathrm{mg} / \mathrm{dl}$ ) and one by hypertension requiring treatment with a converting enzyme inhibitor (case 3 ).

\section{Discussion}

Hepatitis B virus is an aetiological factor of polyarteritis nodosa ${ }^{12} 10$ and it has been suggested that circulating hepatitis $\mathrm{B} \mathrm{Ag} / \mathrm{Ab}$ immune complexes have an important role in the pathogenesis of vasculitic lesions. ${ }^{11}$ On theoretical grounds, the existence of a chronic HBV infection with a high level of virus replication should require a specific approach because steroids are known to enhance viral replication, favour the exacerbation of chronic hepatitis ${ }^{12}$ and ultimately the progression towards liver cirrhosis. We proposed a new therapeutic sequence to obtain the following effects: initial administration of steroids to rapidly control the most severe, lifethreatening manifestations of polyarteritis nodosa which are common during the first weeks of the disease; rapid discontinuation of steroids to trigger a rebound of immunological clearance of HBV-infected hepatocytes and favour seroconversion from $\mathrm{HBeAg}$ to anti$\mathrm{HBeAb}$ as documented for chronic hepatitis $\mathrm{B} ;{ }^{13}$ plasma exchanges to remove pathogenic circulating immune complexes ${ }^{8}$ and prevent further damage especially after steroid withdrawal; administration of an antiviral agent (Vira A, INFa2b) to induce $\mathrm{HBeAg}$ /anti$\mathrm{HBeAb}$ seroconversion.

At the time of our first study, ${ }^{7}$ Vira A was the most effective antiviral agent available against HBV. The overall therapeutic results obtained were excellent: 24 of 33 patients $(72 \cdot 7 \%)$ no longer had any symptoms of vasculitis following therapy and none relapsed during the prolonged follow up period. Seventeen of the 33 patients $(51.5 \%)$ no longer exhibited serological evidence of $\mathrm{HBV}$ replication. Considering the favourable results obtained with Vira A, we decided to test new antiviral agents, such as $I N F a 2 b$, in the treatment of HBV-related PAN. Until 1988, HBV-related PAN accounted for one third $(36 \%)$ of all cases of systemic PAN ${ }^{4}$ studied in France by our group. Since 1987, its frequency progressively decreased and represented less than $10 \%$ of all cases of PAN we observed between 1990-92. Although only a small number of patients has been included in the study, the therapeutic results obtained are promising. All the patients recovered completely from PAN and are still alive at the end of the study. The combination of $\mathrm{INFa} 2 \mathrm{~b}$ and plasma exchanges is well tolerated by patients and only minor side effects were observed. $\mathrm{HBeAg} /$ anti-HBeAb seroconversion was observed in four patients $(66.6 \%)$ and $\mathrm{HBsAg} /$ anti-HBsAb seroconversion occurred in three $(50 \%)$. Our results lead us to think that antiviral therapy will have a role to play in the treatment of virus induced vascular disease and $\mathrm{HBV}$-related PAN, as recently described for cryglobulinemia associated with hepatitis $C$ virus. ${ }^{14}$ It has been feared that INFa2b would worsen immune complexmediated diseases by depressing suppressor T-cell function and enhancing HLA expression. ${ }^{15}$ We did not observe such effects.

In HBV-related PAN, the association of $\mathrm{INFa} 2 \mathrm{~b}$ and plasma exchanges is effective, and facilitates recovery from the vasculitis and $\mathrm{HBeAg} /$ anti-HBeAb seroconversion.

This work was supported by grants from the Association pour la Recherche sur les Angéites Nécrosantes (ARAN) and the Assistance Publique-Hôpitaux de Paris (AP-AH). Research was carried out with the help of the Cooperative Study Group for Polyarteritis Nodosa and the Société Nationale Française de Médecine Interne (SNFMI).

Presented at the 57th annual meeting of the American College of Rheumatology, 7-11 November 1993, San Antonio, Texas, of Rh.

1 Trépo C, Thivolet J. Hepatitis associated antigens and periarteritis nodosa (PAN). Vox Sang 1970; 19: 410.

2 McMahon B J, Heyward W L, Templin D W, Clement D, Lanier A P. Hepatitis B-associated polyarteritis nodosa in Alaskan eskimos: clinical and epidemiologic features and long-term follow up. Hepatology 1989; 9: 97-101.

3 Lightfoot R W, Michel B A, Bloch D A, et al. The American College of Rheumatology 1990 criteria for the classification of polyarteritis nodosa. Arthritis Rheum 1990; 33: 1088-93. 
4 Guillevin L, Le Thi Huong D, Godeau P, Jais J Ph, Wechsler $\mathrm{B}$. Clinical findings and prognosis of polyarteritis nodosa and Churg-Strauss angiitis: a study in 165 patients. Br f Rheumatol 1988; 27: 258-66.

5 Guillevin L, Jarrousse B, Lok C, et al. Long-term follow up after treatment of polyarteritis nodosa and Churg-Strauss angitis with comparison of angiitis with comparison of steroids, plasma exchange and cyclophosphamide to steroids and plasma exchange. A prospective randomized trial of 71 patients. $\mathcal{F}$ Rheumatol 6 Guillevin 18 : 567-74.

uillevin L, Lhote F, Jarrousse B, et al. Polyarteritis nodosa related to hepatitis B virus. A retrospective study of 66 patients. Ann Med Interne 1992; 143: 63-74

7 Guillevin L, Lhote F, Léon A, Fauvelle F, Vivitski L, Trépo C. Treatment of polyarteritis nodosa related to hepatitis B virus with short-term steroid therapy associated with antiviral agents and plasma exchanges. A prospective trial in 33 patients. 7 Rheumatol 1993; 30: 289-98.

8 Blétry O, Bussel A, Badelon I, et al. Intérêt des échanges plasmatiques au cours des angéites nécrosantes. 11 observations. Presse Méd 1982; 11:2827-31.

9 Hantz O, Ooka T, Vitvitski L, Pichoud C, Trépo C. Comparison of properties of woodchuck hepatitis virus
and human hepatitis B virus endogenous DNA polymerases. Antimicrob Agents Chemother 1984; 25: $242-6$

10 Scott D G I, Bacon P A, Elliott P J. Systemic vasculitis in a district general hospital 1972-1980: clinical and laboratory features, classification and prognosis in 80 cases. $Q \mathcal{F}$ Med 1982; 203: 292-311.

11 Trépo C, Zuckerman A J, Bird R C, Prince A M. The role of circulating hepatitis B antigen/antibody immune complexes in the pathogenesis of vascular and hepatic complexes in the pathogenesis of vascular and hepatic 27: 863-86.

12 Lam K C, Lai C L, Trépo C, Wu P C. Deleterious effects of prednisone in HBs Ag-positive chronic hepatitis. $N$ Engl f Med 1981; 304: 380-6.

13 Wood J R, Czaja A J, Taswell H G, Ludwig J, Rakela J, Chase R. Hepatitis B virus desoxyretronucleic acid in serum during hepatitis $\mathrm{Be}$ antigen clearance in corticosteroid-treated severe chronic active hepatitis B. Gastroenterology 1987; 93: 1225-30.

14 Knox T A, Hillyer C D, Kaplan M M, Berkman E M. Mixed cryoglobulinemia responsive to interferon alpha. Am ₹ Med 1991; 91: 554-5.

15 Papo T, Marcellin P, Bernuau J, Durand F, Poynard T, Benhamou J. Autoimmune chronic hepatitis exacerbated by alpha-interferon. Ann Intern Med 1992; 116: 51-53. 